\title{
ПОШИРЕНІСТЬ ТА СТРУКТУРА ХВОРОБ РАТИЦЬ У КОРІВ У ГОСПОДАРСТВАХ РЕСПУБЛІКИ КАЗАСТАН ТА ГРУЗІІ
}

\author{
Стоцький Андрій Олександрович \\ аспірант кафедри кафедри ветсанекспертизи, мікробіології, зоогігієни та безпеки і якості продуктів тваринництва \\ Сумський національний аграрний університет (м. Суми, Україна) \\ ORCID: 0000-0003-0127-7397 \\ stotskyi.andrii@gmail.com \\ Стоцький Олександр Григорович \\ кандидат ветеринарних наук, доцент \\ Сумський національний аграрний університет (м. Суми, Україна) \\ ORCID: 0000-0001-5247-5268 \\ sog61@ukr.net
}

\begin{abstract}
Встановлено, що серед обстежених корів за безприв'язного утримання, кількість виявлених хворих на МТФ Марткопі - Бага (Грузія) перевищувала показник КХ Табис (республіка Казахстан).

У корів в господарстві в Грузії значно розповсюджені захворювання дистального відділу кінцівок (пододерматити, фрлегмони), які виявлялися більше ніж у четверті тварин і перевищували показник у господарстві республіки Казахстан. Ендометрити частіше діагностувалися у тварин господарства КХ Табис, майже 25\%, в той час як на МТФ Марткопі Бага їх відсоток був на 11,25\% меншим. Мастити у корів, в обстежених нами господарствах, реєструвалися майже 8 рівних відсотках тварин, при більшій кількості, на 0,28\%, у КХ Табис.

При аналізі продуктивності на одну фуражну корову, нами встановлено, що у корів господарства республіки Казахстан надій знаходився на рівні 7,5 тис літрів молока, в той час як на молочно-товарній фермі Грузії близько 8 тис. Слід зазначити, що утримання корів та нетелів в господарствах безприв'язне, по 40 - 50 тварин в одній секції протягом року.

При обстеженні нетелів нами виявлені тварини, які мали захворювання дистального відділу кінцівок (гнійні пододерматити, фрлегмони вінчика, м'якуша та між пальцевого склепіння), майже у 40 \% на МТФ Марткопі - Бага, в той час як у тварин KX Табис їх відсоток був меншим в 2,09 рази. Однією із основних причин виникнення захворювань дистального відділу кінцівок у великої рогатої на МТФ Марткопі - Бага, є несвоєчасна ортопедична розчистка ратиць, що крім того сприяло їх деформації та зміні поставок кінцівок у тварин.

В зазначених господарствах кількість утримуваних тварин суттєво відрізнялася. Так, на МТФ Марткопі - Бага їх було на 96 голів менше ніж нетелів у КХ Табис республіки Казахстан і структура виявлених захворювань також мала певну відмінність.

Деформації ратиць у корів на МТФ Марткопі - Бага реєструвалися на 11,33\% частіше ніж у тварин КХ Табис, що в подальшому і було однією із причин виникнення запальний процесів ділянки пальия. Найбільший відсоток серед деформацій ратиць, в обстежених господарствах становили гострокутні копития, які реєструвалися майже у 10,0\% корів в господарстві Грузії і перевищував показник в господарстві республіки Казахстан в 1,67 рази. Досить значний відсоток деформацій ратиць у тварин в обстежених господарствах припадав на гострокутні та криві копития, становлячи показник 8 межах 5-9 відсотків. Слід відмітити, що зазначені деформацій ширше були розповсюдженні у великої рогатої худоби на МТФ Марткопі - Бага.

Аналізуючи дані стосовно інших деформацій видно, що в господарстві республіки вони мали вищі показники. Так, відсоток тупокутних копитець на МТФ Марткопі - Бага перевищував аналогічний у КХ Табис на 1,65\%, плоских на 3.04\%, і майже на одному рівні за розповсюдженням реєструвався відсоток повних.
\end{abstract}

Ключові слова: Opтопедична патологія, ендометрити, мастити.

DOI:https://doi.org/10.32845/bsnau.vet.2019.1-2.1

Вступ. Однією із нагальних проблем як світового, так і вітчизняного молочного скотарства $є$ значне поширення акушерської, гінекологічної та ортопедичної патології, яке зумовлене багатофакторним впливом біотичних і абіотичних чинників на організм корів. При цьому розвиток і перебіг цих хвороб нерідко ускладнюється патологією обміну речовин чи специфічними інфекційно-запальними процесами.

Опорно-рухова система $є$ однією із найбільш чутливих, тож не дивно, що хвороби кінцівок у ВРХ зустрічаються дуже часто. В середньому близько 10\% стада на підприємствах страждає на хвороби копит (Веремей Э.И., Журба В.А., Лапина В.А.,,2003). За даним інших авторів (Попов Ю.Г., Шкиль Н.А., Дровосеков Н.А., 2004, Лукъяновский В.А., 2007) в окремих господарствах ураження копитець зустрічається у

30-87\% корів, що завдає серйозної економічної шкоди, і виражається у зниженні середньодобових надоїв у 28-42\% (Елисеев А.Н., Коломийцев С. М., Бледнов А.В. та ін). , подовженні сервіс-періоду, зменшенню виходу телят на 18\% (Тимофеев С.В., Филиппов Ю.И., Гимранов В.В., 2009), передчасній вибраковці хворих тварин у 50-60\% (Власенко С.А., 2017) та підвищенню ротації поголів'я.

Копитця являються одним із важливих органів великої рогатої худоби, забезпечуючи опору та пересування їх. Неправильна експлуатації корів та недотримання зоогігієнічних вимог щодо приміщень тваринниками, створюють ідеальні можливості до виникнення десформацій ратиць.

За даними літератури, виправлення такої патології процес тривалий і неприємний, особливо, якщо поголів'я великої рогатої худоби велике, тому краще попереджати такі 
явища.

У великої рогатої худоби виділяють наступні види деформації копит, які реєструвалися і нами:

- довгі (гострокутні);

- криві;

- плоскі копитця;

- повні;

- косі копитця;

- торцеві.

Довгі (гострокутні) копитця - мають подовжену зачіпну частину. Кут між зачіпною частиною і підошвою менше $45^{\circ}$. Підошовний край стінки зазвичай загинається вгору. Іноді, за довгих копитець вони можуть перехрещуватися з іншим, поруч розташованим.

Етіологічними факторами, які сприяють утворенню такої деформації, є: відсутність тривалих прогулянок або вигулів тваринами взагалі, несвоєчасна розчистка ратиць, наявність патологій в області кінцівок та неправильна їх постава.

Корови з гострокутними деформованими копитами виставляють кінцівку вперед і переносять вагу тіла на задні ділянки копитець, що нами і відмічалося у тварин. Іноді нами також реєструвалося заламування довгих копитець. Виправлення такої деформації можливе лише за ретельної ортопедичної їх розчистки.

При цьому слід пам'ятати, що в деякий випадках патологія може носити спадковий характер і практично не піддається виправленню, тому таких тварин не допускають до відтворення потомства.

Плоске копито - деформація, яка характеризується знаходженням підошви на одному рівні з підошовним краєм роговий стінки. Зачіпна та бічні частини стінки пологі. Ріг підошви пухкий, нерівний. Рогова підошва зазвичай тонка, швидко стирається, що може в подальшому спричинити навіть до розвитку дерматиту.

Повні копита - вид десрормації кінцівки, при якому підошва виступає нижче підошовного краю рогової стінки. У свою ж чергу ріг підошви пухкий. У корови спостерігається утиск основи шкіри і кульгавість при ходьбі.

Торцеві копитця - десоормація, за якої при постановці зачіпної стінки і ґрунту утворюється прямий кут. При цьому варто відзначити, що з зачіпна частина і м'якушна стінки мають одну висоту (Лукъяновский В.А. та ін., 1998-2012, Марьин Е.М. та ін 2000-2015, Якоб В.К., 2013)

Криві (стислі) копитця - вид деформування, при якому зовнішня сторона кінцівки опукла, а внутрішня увігнута. У великої рогатої худоби така патологія зустрічається дуже часто. Це пов'язано з тим, що у них аксіальні стінки увігнуті, а абаксіальні - опуклі. При такій дефрормації, не може бути одне копитце деформованим, зазвичай страждають обидві кінцівки. Трапляються ситуації, коли абаксіальна стінка загинається за підошву. В результаті такої деформації корови пересуваються повільно, іноді спостерігається кульгавість.

Однак варто зазначити, що така деформація найчастіше утворюється саме на тазових кінцівках, ніж на грудних.

Етіологічними факторами, які сприяють появі даної патології, є: спадкова схильність, похибки в годівлі та утриманні тварин, внаслідок чого копитний ріг стає м'яким, легко згинається і сприяє появі викривлень.

За даними авторів, молоді телята, які тривалий час утримуються в тісних і вузьких приміщеннях, без доступу пересування в майбутньому вже будуть страждати деформаціями кінцівки. У тварин з кривими копитцями вісь пальців кісток надламується. У свою ж чергу на зовнішній стороні пальців при такій патології можуть утворюватися доброякісні кістковохрящові нарости (екстози) в місці прикріплення колатеральних зв'язок (Лукъяновский В.А. та ін., 1998-2012, Марьин Е.М. та ін. 2000-2015, Якоб В.К., 2013).

Лікувальні заходи зводяться до обрізки копит, а в більш важких випадках роблять таку маніпуляцію кілька разів.

Косе копитце - деформація, яка зустрічається дуже порівняно і найчастіше на зовнішньому копитці.

Будь-яка деформація копит може бути виправлена, якщо ж звичайно, вона не носить спадкових характер. Досить буде лише провести розчистку копитець, покращити умови утримання тварини, поліпшити годівлю і тоді деформації копитець у корів можуть і не бути, або ж реєструватимуться поодинокі випадки.

Слід зазначити, що деформації копитець у великої рогатої худоби явище досить часте, але правильний догляд за тваринами дозволить зберегти копитця в нормальному стані.

Таким чином, патологія копитець у високопродуктивних корів $є$ актуальною проблемою тваринництва та потребує подальшого вивчення патогенезу та удосконаленню методів терапії.

У зв'язку з цим метою роботи було вивчити розповсюдження захворювань дистального відділу кінцівок та їх асоційований зв'язок з виникненням ендометритів та маститів у корів в умовах молочно-товарних ферм республіки Казахстан та Грузії.

Для вирішення поставленої мети необхідно вирішити наступні завдання:

провести аналіз розповсюдження захворювань ратиць у корів на молочно товарних фермах в залежності від умов утримання в господарствах республіки Казахстан та Грузії;

провести аналіз асоційованого зв'язку між проявом ортопедичної патології та акушерсько-гінекологічними захворюваннями у продуктивних тварин в господарствах республіки Казахстан та Грузії;

Матеріали та методи досліджень. Дослідження проводилися в умовах молочно товарних ферм республіки Казахстан та Грузії. На молочно-товарній фермі республіки Казахстан утримуються корови та нетелі завезені з України, а в Грузії з Естонії. Шляхом проведення диспансеризації нами були враховані наявні клінічні ознаки за патології ратиць, ендометритів та маститів у корів та патології ратиць у нетелів.

\section{Результати та їх обговорення.}

Протягом 6 місяців виробничого стажування в господарствах республіки Казахстан та Грузії (3 місяці в кожному із зазначених) нами проводилося диспансерне обстеження поголів'я великої рогатої худоби. Дані проведеної диспансеризації корів та нетелів в зазначених господарствах представлені в таблицях 1, 2 i 3.

Як видно з даних таблиці 1 структура захворюваності корів в господарствах мала суттєву різницю.

Так, серед обстежених корів за безприв'язного утримання, кількість виявлених хворих тварин на МТФ Марткопі Бага (Грузія) на 22,99\% перевищувала показник СГ Табис (республіка Казахстан). 
Дані обстеження поголів'я корів в господарствах республіки Казахстан та Грузії

\begin{tabular}{|c|c|c|c|c|}
\hline \multirow[t]{2}{*}{ Показник } & \multicolumn{2}{|c|}{$\begin{array}{c}\text { Республіка Казахстан } \\
\text { СГ Табис }\end{array}$} & \multicolumn{2}{|c|}{$\begin{array}{c}\text { Грузія } \\
\text { МТФ Марткопі - Бага }\end{array}$} \\
\hline & гол & $\%$ & гол & $\%$ \\
\hline Обстежено & 200 & 100 & 151 & 100 \\
\hline Виявлено хворих, всього & 56 & 28,0 & 77 & 50,99 \\
\hline Патологія копитець (пододерматити, фрлегмони, тощо) & 15 & 7,5 & 37 & 24,5 \\
\hline Ендометрити & 19 & 9,5 & 20 & 13,25 \\
\hline Мастити & 14 & 7,0 & 10 & 6,62 \\
\hline Ендометрити та мастити & 4 & 2,0 & 2 & 1,33 \\
\hline Хвороби копитець та ендометрити & 2 & 1,0 & 5 & 3,31 \\
\hline Хвороби копитець та мастити & 1 & 0,5 & 2 & 1,33 \\
\hline Хвороби копитець, ендометрити, мастити & 1 & 0,5 & 1 & 0,7 \\
\hline
\end{tabular}

Слід відмітити, що у корів в господарстві Грузії значно розповсюджені захворювання дистального відділу кінцівок (пододерматити, флегмони), які виявлялися майже у четверті тварин і перевищували показник у господарстві республіки Казахстан на $17,0 \%$.

Аналізуючи дані стосовно ендометритів у корів, нами встановлено значне розповсюдження їх у тварин господарства СГ Табис, майже 10,0,\%, в той час як на МТФ Марткопі Бага їх відсоток був на $3,75 \%$ вищим. Мастити у корів, в обстежених нами господарствах, реєструвалися майже в рівних відсотках тварин, при більшій кількості, на 0,28\%, у СГ Табис.
При аналізі продуктивності на одну фуражну корову, нами встановлено, що у корів господарства республіки Казахстан надій знаходився на рівні 7,5 тис літрів молока, в той час як на молочно-товарній фермі Грузії близько 8 тис.

Слід зазначити, що утримання корів та нетелів в господарствах безприв'язне, по 40 - 50 тварин в одній секції протягом року.

При обстеженні нетелів нами виявлені тварини, які мали захворювання дистального відділу кінцівок (гнійні пододерматити, флегмони вінчика, м'якуша та між пальцевого склепіння) (табл. 2).

Таблиця 2

Розповсюдження захворювань ратиць у нетелів в господарствах республіки Казахстан та Грузії

\begin{tabular}{|l|c|c|c|c|}
\hline \multirow{2}{*}{ Показник } & \multicolumn{2}{c|}{$\begin{array}{c}\text { Казахстан } \\
\text { СГ Табис }\end{array}$} \\
\cline { 2 - 5 } & гол & \multicolumn{3}{c|}{ МТузія Мартопі - Бага } \\
\hline Обстежено & 120 & 100 & 73 & гол \\
\hline Патологія копитець (пододерматити, фрлегмони, тощо) & 22 & 18,33 & 28 & 38,36 \\
\hline
\end{tabular}

Як видно з даних представлених в таблиці 2 майже у 40 \% нетелів МТФ Марткопі - Бага виявлялися захворювання ратиць, в той час як у тварин СГ Табис їх відсоток був меншим в 2,09 рази.

В подальшому, за неналежного лікування тварин та ускладнень відсоток вибраковки буде вищим у великої рогатої худоби в господарстві МТФ Марткопі - Бага.
Однією із основних причин виникнення захворювань дистального відділу кінцівок у великої рогатої на МТФ Марткопі - Бага, є несвоєчасна ортопедична розчистка ратиць, що крім того сприяло їх деформації та зміні поставок кінцівок у тварин (табл. 3).

Розповсюдження деформацій ратиць у тварин республіки Казахстан та Грузії

\begin{tabular}{|l|c|l|c|c|}
\hline \multirow{2}{*}{\multicolumn{1}{c|}{ Показник }} & \multicolumn{2}{c|}{$\begin{array}{c}\text { Казахстан } \\
\text { СГ Табис }\end{array}$} \\
\cline { 2 - 5 } & гол & \multicolumn{2}{c|}{$\begin{array}{c}\text { Грузія } \\
\text { МТФ Марткопі - Бага }\end{array}$} \\
\hline Обстежено & 320 & 100 & 224 & 100 \\
\hline Дерормації ратиць, всього & 38 & 11,88 & 52 & 23,21 \\
\hline В тому числі & & & & \\
\hline Гострокутні копитця & 18 & 5,63 & 21 & 9,38 \\
\hline Тупокутні копитця & 9 & 2,81 & 10 & 4,46 \\
\hline Плоскі копитця & 6 & 1,87 & 11 & 4,91 \\
\hline Повні копитця & 13 & 4,06 & 13 & 5,80 \\
\hline Криві копитця & 16 & 5,00 & 16 & 7,14 \\
\hline
\end{tabular}

Слід відмітити, що у корів в господарстві Грузії значно розповсюджені захворювання дистального відділу кінцівок (пододерматити, флегмони), які виявлялися майже у четверті тварин і перевищували показник у господарстві республіки Казахстан на $17,0 \%$.

Так, на МТФ Марткопі - Бага їх було на 96 голів менше ніж нетелів у СГ Табис республіки Казахстан і структура виявлених захворювань також мала певну відмінність.

Деформації ратиць у корів на МТФ Марткопі - Бага реєструвалися на 11,33\% частіше ніж у тварин СГ Табис, що в подальшому і було однією із причин виникнення запальний процесів ділянки пальця.

Найбільший відсоток серед деформацій ратиць обстежених господарствах становили гострокутні копитця, які реєструвалися майже у 10,0\% корів в господарстві Грузії і перевищував показник в господарстві республіки Казахстан в 1,67 рази.

Досить значний відсоток деформацій ратиць у тварин 
в обстежених господарствах припадав на гострокутні та криві копитця, становлячи показник в межах 5-9 відсотків. Слід відмітити, що зазначені деформацій ширше були розповсюдженні у великої рогатої худоби на МТФ Марткопі - Бага.

Аналізуючи дані стосовно інших деформацій видно, що в господарстві Грузії вони мали вищі показники.

Так, відсоток тупокутних копитець на МТФ Марткопі Бага перевищував аналогічний у СГ Табис на 1,65\%, плоских на $3.04 \%$, і майже на одному рівні за розповсюдженням реєструвався відсоток повних.

У подальшому нами проводився аналіз структури захворюваності ратиць у великої рогатої худоби в обстежених господарствах (табл.. 4).

Дані представлені в таблиці 4 свідчать, що в обстеже- них господарствах відмічаються подібні захворювання дистального відділу кінцівок у великої рогатої худоби, що на нашу думку пов'язано з порушенням зоогігієнічних умов утримання, як однією з основних причин їх виникнення.

Так, серед 320 голів великої рогатої худоби в СГ Табис патологія ратиць діагностувалася у 37 випадках, що становило 11,56\% від загальної кількості тварин в господарстві.

В господарстві Грузії на МТФ Марткопі - Бага відсоток тварин з патологією ратиць був значно вищим і становив $32,59 \%$, перевищуючи показник СГ Табис в 2,82 рази.

Слід зазначити, що у структурі патології дистального відділу кінцівок, як у корів так і нетелів, реєструвалися відмінності у відсотку представлених хвороб.

Таблиця 4

Структура патології дистального відділу кінцівок у великої рогатої худоби в досліджуваних господарствах

\begin{tabular}{|l|c|c|c|c|}
\hline \multirow{2}{*}{ Патологія } & \multicolumn{2}{c|}{ СГ Табис } & \multicolumn{2}{c|}{ МТФ Марткопі - Бага } \\
\cline { 2 - 5 } & гол & $\%$ & гол & 100 \\
\hline Корови & 200 & 100 & 151 & 24,44 \\
\hline Поверхневі гнійні пододерматити & 2 & 13,33 & 11 & 6,67 \\
\hline Глибокі гнійні пододерматити & 1 & 6,67 & 3 & 48,89 \\
\hline Флегмона вінчика, м'якуша та між пальцевого склепіння & 7 & 46,67 & 22 & 20,0 \\
\hline Виразка Рустергольца & 5 & 33,33 & 9 & 29,8 \\
\hline Всього & 15 & 7,5 & 45 & 100 \\
\hline Нетелі & 120 & 100 & 73 & 35,71 \\
\hline Поверхневі гнійні пододерматити & 5 & 22,73 & 10 & 10,71 \\
\hline Глибокі гнійні пододерматити & 2 & 9,09 & 3 & 42,86 \\
\hline Флегмона вінчика, м'якуша та між пальцевого склепіння & 10 & 45,45 & 12 & 10,71 \\
\hline Виразка Рустергольца & 5 & 22,73 & 3 & 38,36 \\
\hline Всього & 22 & 18,33 & 28 & \\
\hline
\end{tabular}

Так, у корів СГ Табис та на МТФ Марткопі - Бага у структурі захворюваності ратиць переважали флегмонозні процеси в ділянці вінчика, м'якуша та між пальцевого склепіння становлячи майже 50,0\% від загальної кількості хворих тварин.

В більшій мірі у корів реєструвалися пододерматити (поверхневий, глибокий та виразковий), становлячи 53,33\% у тварин СГ Табис та 51,2 \% на МТФ Марткопі - Бага.

У структурі пододерматитів в обстежених господарствах вони мали різні показники.

Так, у корів СГ Табис значно розповсюдженими були виразкові пододерматити, становлячи більше третини від загальної кількості хворих, в той час, як поверхневі та глибокі гнійні реєструвалися в поодиноких випадках.

У корів на МТФ Марткопі - Бага частіше реєструвалися поверхневий гнійний пододерматит становлячи майже одну четверту від загальної кількості хворих, та менший на 4,44 \% виразковий пододерматит.

Слід зазначити, що глибокі гнійні пододерматити, у корів в господарствах реєструвалися у різної кількості тварин, але становили однаковий відсоток.

При дослідженні нетелів нами встановлено, що патологія ратиць у них реєструвалася частіше у порівнянні з коровами.

Так, у нетелів СГ Табис їх відсоток перевищував показник у корів в 2,44 рази, а на МТФ Марткопі - Бага лише на 9,36\%.

Крім того, як у корів так і у нетелів відсоток флегмонозних процесів пальця був досить високим, але у нетелів, в обох господарствах, він був дещо нижчим ніж у корів, але при більшому показнику в СГ Табис.
У структурі пододерматитів у нетелів в господарстві республіки Казахстан СГ Табис переважали поверхневі гнійні та виразковий пододерматит, становлячи однаковий показник, і в поодиноких випадках, як і у корів реєструвалися глибокі гнійні пододерматити.

Аналізуючи дані обстеження нетелів на МТФ Марткопі - Бага у структурі пододерматитів були інші показники, які відрізнялися від показників у корів.

Так, найбільший відсоток становили поверхневі гнійні пододерматити, перевищуючи аналогічний показник нетелів СГ Табис в 1,57 рази.

Відсоток випадків виразки Рустергольца у нетелів на МТФ Марткопі - Бага був нижчим ніж у тварин СГ Табис в 2,12 рази, при невираженій різниці у показниках глибоких гнійних пододерматитів, в межах 10,0\%.

При клінічному дослідженні нами встановлені клінічні ознаки характерні для кожного патологічного процесу ділянки пальця у великої рогатої худоби.

При клінічному обстеженні корів нами встановлено, що флегмона в області вінчика та між пальцевого склепіння протікала в формі гнійного запалення в поодиноких випадках виявляли гнійно-некротичні флегмони підшкірного шару, основи шкіри копитного вінчика, облямівки і волосистої шкіри на кордоні з рогової капсулою.

Основною причиною виникнення флегмон були інфіковані рани та мацерацією тканин при несвоєчасному видаленні гноївки.

При клінічному дослідженні хворих корів відмічали підвищення температури тіла до $39,7^{\circ} \mathrm{C}$, пригнічення, млявий прийом корму та залежуванням. 
У хворих тварин спостерігалася кульгавість опертої кінцівки сильного ступеня. Припухлість локалізувалася по всьому вінчику, гаряча та значно болюча на дотик.

Крім флегмон ділянки пальця у корів та телиць нами реєструвалися випадки гнійного пододерматиту, що виникали внаслідок ускладнень тріщини копитного розу при несвоєчасній ортопедичній їх обробці.

Клінічно захворювання супроводжувалося кульгавістю опертої кінцівки сильного ступеня, підвищенням температури копитець, посиленою пульсацією пальцевих артерій, залежуванням, підвищенням температури тіла на $0,5^{\circ} \mathrm{C}$.

В поодиноких випадках у тварин реєстрували виразковий пододерматит протягом року, в той час як за даними інших авторів (цит. Н.М. Хомин, 2017) захворювання частіше виявляють у весняний та осінній періоди, рідше - влітку та взимку.

У 91,6\% випадків виразка локалізувалася на латеральному і лише у 8,4\% - на підошві медіального копитця.

Подібна тенденція щодо їх локалізації реєструвалася і в наших дослідженнях з незначним коливаннями.

За нашими даними, основною причиною виникнення виразки м'якуша у обстежених господарствах є посилене навантаження на центральну частину підошви копитця у зв'язку з невчасною ортопедичною розчисткою копитець, що ми і реєстрували.

\section{Висновки.}

1.Деформації ратиць у корів та нетелів зумовлені несвоєчасною ортопедичною їх обробкою.

2.Захворювань ратиць у корів та нетелів в обстежених господарствах пов'язані з деформацією ратиць та несвоєчасною ортопедичною їх обробкою в подальшому.

3.В поодиноких випадках прослідковується асоційований зв'язок у виникненні захворювань ратиць у корів та акушерсько-гінекологічної патології.

Перспективи подальших досліджень. 3 метою встановлення асоційованого зв'язку у виникненні ортопедичної патології та акушерсько-гінекологічних захворювань, нами планується проведення лабораторних досліджень гнійного ексудату відібраного від хворих тварин, з метою вивчення складу мікрофлори та її чутливості до антибактеріальних препаратів з подальшим використанням таких препараті за даної патології.

\section{Список використаної літератури:}

1. Vlasenko S. A., Rublenko M. V. (2012). Produktsiia oksydu azotu ta bilkiv hostroi fazy za hestatsiinoho protsesu, metrytu i ortopedychnoi patolohii u koriv. [Production of nitric oxide and acute phase proteins in gestational process, metritis and orthopedic pathology in cows] Biolohiia tvaryn, [Animal biology], 14, 1-2, 361 - 369.

2. Veremej E'.l., Zhurba V.A., Lapina V.A. (2003). E'tiopatogenez i sovremenny’e podkhody` k lecheniyu gnojnonekroticheskikh proczessov v oblasti kopy'tecz i pal'czev u KRS [Etiopathogenesis and modern approaches to the treatment of purulent-necrotic processes in the field of hooves and fingers in cattle]. Veterinarny'j konsul' tant. [Veterinary Consultant ], 16, 17-19.

3. Luk'yanovskij V.A. (1998). Vliyanie uslovij soderzhaniya na temperaturu razlichny'kh uchastkov tela i ortopedicheskuyu patologiyu u korov. [The influence of conditions on the temperature of various parts of the body and orthopedic pathology in cows]. Veterinariya. [Veterinary Medicine], 11, 36-38.

4. Maslov M.V. (2010). Profilakticheskie i lechebny`e meropriyatiya pri boleznyakh kopy`tecz u korov. [Preventive and therapeutic measures for diseases of the hooves of cows]. Veterinariya Kubani [ Veterinary medicine of Kuban], 2, 11-15.

5. Popov Yu.G., Shkil N.A., Drovosekov N.A. (2004) Zabolevaniya krupnogo rogatogo skota, vy’zy’vaemy’e uslovnopatogennoj mikrofloroj [Cattle diseases caused by conditionally pathogenic microflora] RASKhN - Sib. otd-nie. IE' VSiDV, NGAU, ZAO Rosvetfarm. Novosibirsk, 35-43.

6. Luk yanovskij V.A. (1997). Biotekhnologicheskie zakonomernosti vozniknoveniya ortopedicheskikh boleznej u korov. [Biotechnological patterns of the occurrence of orthopedic diseases in cows] Veterinariya [Veterinary Medicine],10, 35-41.

7. Kalashnik I.A. (1991). Zabolevanie kopy'tecz u korov pri razlichny'kh sistemakh ikh soderzhaniya v kompleksakh po proizvodstvu moloka. [Disease of the hooves in cows with various systems of their maintenance in complexes for the production of milk] Problemy' khirurgicheskoj patologii sel 'skokhozyajstvenny'kh zhivotny'kh: tr. dokl. vsesoyuz. nauch. konf. Belaya Czerkov' [Problems of surgical pathology of farm animals: scientific conf. Bila Tserkva], 67-68.

8. Eliseev A.N., Kolomijczev S. M., Blednov A.V. i dr. (2000). Lechenie gnojno-nekroticheskikh porazhenij tkanej pal'czev u skota. [Treatment of purulent-necrotic lesions of finger tissue in cattle] Veterinariya [Veterinary Medicine], 12, 43-44.

9. Timofeev S.V., Filippov Yu.I., Gimranov V.V. (2009). Bolezni kopy tecz i tekhnologiya ortopedicheskoj dispanserizaczii. [Hoof diseases and orthopedic medical examination technology] Veterinarnaya mediczina. [Veterinary medicine], 1-2, 78-80.

10. Vlasenko S.A. (2017). Patohenetychni mekhanizmy porushen reproduktyvnoi funktsii u vysokoproduktyvnykh koriv za hniino-nekrotychnykh urazhen $v$ diliantsi paltsiv [ Pathogenetic mechanisms of impaired reproductive function in high-performance cows with purulent-necrotic lesions in the finger area ] Avtoreferat dysertatsii na zdobuttia naukovoho stupenia doktora veterynarnykh nauk za spetsialnistiu 16.00.05-veterynarna khirurhiia ta 16.00.07-veterynarne akusherstvo. Bila Tserkva [Thesis for a doctorate degree in veterinary sciences, specialty 16.00.05-veterinary surgery and 16.00.07-veterinary obstetrics. Bila Tserkva], 41.

11. N.M. Khomyn, A.R. Mysak, I.I. Ihlitskyi, V.V. Pritsak (2017). Poshyrenist ta prychyny vynyknennia khvorob kopytets u koriv [Prevalence and causes of hoof disease in cows ] Naukovyi visnyk Lvivskoho natsionalnoho universytetu veterynarnoi medytsyny ta biotekhnolohii imeni S.Z. Gzhytskoho [Scientific Bulletin of Lviv National University of Veterinary Medicine and Biotechnology], 19, 77, $22-26$.

12. Batrakov A.Ya. (2010). Profilakticheskie i lechebny'e meropriyatiya pri zabolevaniyakh kopy`tecz u korov [Preventive and curative measures in case of hoof disease in cows] Veterinariya [Veterinary medicine], 5, 49-51.

13. V.A. Ermolaev, E.M. Mar' in, V.V. Idogov, Yu.V. Savel'eva (2010). Bolezni kopy' tecz u korov [Cow hoof disease] Ucheny'e zapiski Kazanskoj gosudarstvennoj akademii veterinarnoj medicziny' im. N.E'. Baumana. - Kazan [ Scientific Notes of the Kazan State Academy of Veterinary Medicine. - Kazan], 203, 113 - 117.

Вісник Сумського національного аграрного університету

Серія «Ветеринарна медицина», випуск 1-2 (44-45), 2019 
14. Borisevich, V.B. (1996). Veterinarnaya ortopediya: bolezni kopy`tecz i kopy`t [Veterinary orthopedics: hoof and hoof diseases] Kiev: Kirovogradizdat, 231.

15. Veremej, E'.I. (2003). Rasprostranenie i profilaktika zabolevanij pal'czev i kopy`tecz u krupnogo rogatogo skota / E'.I. Veremej, V.A. Zhurba [ The spread and prevention of diseases of the fingers and hooves in cattle] Veterinarnaya mediczina Belarussii [Veterinary medicine of Belarus], 2, 32-35.

16. Videnin V.N., Gorelenok A.I., Rasulov P.I. (1985). Operativnoe lechenie gnojny `kh porazhenij pal’czev u korov v usloviyakh promy shlennogo kompleksa [Surgical treatment of purulent finger lesions in cows in an industrial complex] Sbornik trudov Leningradskogo veterinarnogo instituta [Proceedings of the Leningrad Veterinary Institute], 82, 6-9.

17. Galimzyanov, I.G., Kutlukaev I.I. (2012). Sposob lecheniya korov pri gnojny`kh artritakh, tendovaginitakh i bursitakh v oblasti pal'czev, [ A method of treating cows with purulent arthritis, tendovaginitis and bursitis in the finger area] Ucheny`e zapiski Kazanskoj gosudarstvennoj akademii veterinarnoj medicziny' im. N.E'. Baumana [ Learning notes of the Kazan State Academy of Veterinary Medicine named after N. Her. Bauman], 210, 57-61.

18. Gimranov, V.V. (2010). Etiologiya, kharakter rasprostranennosti i osobennosti patologij v oblasti pal'czev u korov golshtinofrizskoj porody'N.V. Gimranov, R.A. Uteev, A.F.Gilyazov [ Etiology, nature of prevalence and features of pathologies in the finger area in Holstein-Friesian cows] Agrarny'j vestnik Urala [Agrarniyezh Bulletin of the Urals], 69, 3, 7.

19. Gimranov, V.V.(2006). Klassifikacziya boleznej v oblasti pal'czev u krupnogo rogatogo skota / V.V. Gimranov, S.V. Timofeev [Cattle Disease Classification] Veterinariya [Veterinary science ], 2, 48-49.

20. Gimranov, V.V. (2010). Rezul'taty' ortopedicheskoj dispanserizaczii importnogo skota/ V.V. Gimranov, R.A. Uteev, A.F. Gilyazov [Results of orthopedic medical examination of imported livestock] Dostizheniya nauki i tekhniki APK [Achievements of science and technology of agribusiness], 2, 51-52.

21. Eliseev, A.N. (2000). Lechenie gnojno-nekroticheskikh porazhenij tkanej pal’czev u skota / A.N. Eliseev, S.M. Kolomijczev, A.I. Blednov i dr. [Treatment of purulent-necrotic lesions of finger tissue in cattle] Veterinariya [Veterinary science ], 12, 57-59.

22. Ermolaev V.A. (2015). Dinamika planimetricheskikh pokazatelej zazhivleniya yazvenny`kh defektov v oblasti kopy`tecz u korov, pri kompleksnom ikh lechenii N.A. Ermolaev, E.M. Mar' in, P.M. Lyashenko, A.V. Sapozhnikov, V.K. Yakob [The dynamics of planimetric indicators of the healing of ulcerative defects in the hooves of cows, with their complex treatment ] Materialy' mezhdunarodnoj nauchno-prakticheskoj konferenczii / Aktual'ny'e voprosy' veterinarnoj nauki. - Ul'yanovsk [Materials of the international scientific-practical conference / Actual issues of veterinary science. - Ulyanovsk], 159-162.

23. Ermolaev, V.A. (2010). Bolezni kopy`tecz u korov / V.A. Ermolaev, E.M. Mar’in, V.V. Idogov, Yu.V. Savel’eva [Cow hoof disease] Ucheny’e zapiski Kazanskoj gosudarstvennoj akademii veterinarnoj medicziny' im. N.E'. Baumana. -Kazan’ [Scientific notes of Kazan State Academy of Veterinary Medicine named after N.E. Bauman. -Kazan], 203, 113 -117.

24. Idogov, V.V. (2010). Gematologicheskie pokazateli pri gnojny”kh pododermatitakh u krupnogo rogatogo skota / V.V. Idogov, V.A. Ermolaev, E.M. Mar'in, Yu.V. Savel'eva [Hematological parameters in purulent pododermatitis in cattle] Voprosy’ normativno-pravovogo regulirovaniya v veterinarii. - SPb., [ Regulatory issues in veterinary medicine. - SPb.,], 4, 46 -48.

25. Luk yanovskij, V.A. (1997). Biotekhnologicheskie zakonomernosti vozniknoveniya ortopedicheskikh boleznej u korov / V.A. Luk yanovskij [Biotechnological patterns of orthopedic diseases in cows] Veterinariya [Veterinary science], 10, 35-41.

26. Mar’in, E.M. (2009). Biologicheski aktivny`e dreniruyushhie sorbenty` pri gnojny`kh pododermatitakh u korov / E.M. Mar`in, V.A. Ermolaev, V.V. Idogov, A.V. Sapozhnikov [Biologically active draining sorbents for purulent pododermatitis in cows ] Mezhdunarodny”j vestnik veterinarii. - SPB [ International Journal of Veterinary Medicine. - SPB], 13-16.

27. Mar' in, E.M. (2011). Bolezni kopy 'tecz u korov razlichny'kh porod / E.M. Mar' in, V.A. Ermolaev [Hoof diseases in cows of various breeds] Izvestiya OGAU.- Orenburg [ Izvestiya OGAU.- Orenburg], 2 (30), C.104-105.

28. Mar in, E.M. (2013). Kliniko-gematologicheskie pokazateli pri boleznyakh kopy’tecz u krupnogo rogatogo skota / E.M. Mar' in, O.N. Mar' ina [ Clinical and hematological parameters in diseases of the hooves in cattle] auka v sovremenny kh usloviyakh: ot idei do vnedreniya. [Science in modern conditions: from idea to implementation.], 1, 52-56.

29. Mar'in, E.M. (2012). Kharakteristika ortopedicheskikh patologij u krupnogo rogatogo skota / Mar’ in E.M., Ermolaev V.A., Mar'ina O.N., Raksina I.S. [Characteristics of orthopedic pathologies in cattle] Vestnik Ul'yanovskoj gosudarstvennoj sel'skokhozyajstvennoj akademii [ Bulletin of the Ulyanovsk State Agricultural Academy], 4, 66-69.

30. Maslov M.V. (2010). Profilakticheskie i lechebny`e meropriyatiya pri boleznyakh kopy tecz u korov /M.V. Maslov [Preventive and therapeutic measures for diseases of the hooves of cows] Veterinariya Kubani [Veterinary medicine of Kuban], 2, 11-13.

31. Molokanov, V.A. (1991). E`tiopatogenez zabolevanij kopy`tecz u vy`sokoproduktivny`kh korov / V.A. Molokanov [Etiopathogenesis of hoof diseases in highly productive cows] Problemy' khirurgicheskoj patologii sel'skokhozyajstvenny`kh zhivotny`kh: Tez. dokl. Vsesoyuz. nauch. konf. - Belaya Czerkov` [Problems of surgical pathology of farm animals: Abstract. doc. AllUnion. scientific conf. - White church], 69-70.

32. Khuzin D.A. (2011). Opy`t ozdorovleniya krupnogo rogatogo skota ot zabolevanij kopy`tecz/ D.A. Khuzin, A.V. Ivanov, Kh.N. Makaev, D.A. Latfullin [ Experience in the recovery of cattle from diseases of the hoof] Veterinariya [Veterinary science], 11, 2022.

33. Khuzin D.A. (2011). Opy`t ozdorovleniya krupnogo rogatogo skota ot massovy`kh zabolevanij konechnostej v 000 « Im. M. Dzhalilya» Bugul'minskogo Rajona Respubliki Tatarstan/ D.A.Khuzin, F.A. Khusniev F.A., D.N. Latfullin, N.A. Mukhammetshin [Experience in the recovery of cattle from mass diseases of the limbs at LLC "Im. M. Jalil "of the Bugulma District of the Republic of Tatarstan] Ucheny`e zapiski Kazanskoj gosudarstvennoj akademii veterinarnoj medicziny` im. N.E'. Baumana [Scientific notes of Kazan State Academy of Veterinary Medicine named after N.E. Bauman], 208, 308-309.

34. Stekol'nikov, A.A. (2011). Zabolevaniya konechnostej u krupnogo rogatogo skota pri intensivnom vedenii zhivotnovodstva, 
puti profilaktiki i lecheniya / A.A. Stekol'nikov [Diseases of the limbs in cattle with intensive animal husbandry, ways of prevention and treatment] Materialy` Mezhdunarodnoj konferenczii «Aktual'ny`e problemy` veterinarnoj khirurgii». - Ul'yanovsk [Materials of the International Conference "Actual Problems of Veterinary Surgery". - Ulyanovsk], 3-7.

35. Stekol'nikov, A.A. (2010). O tekhnologicheskikh usloviyakh veterinarnogo obsluzhivaniya molochny'kh kompleksov / A.A. Stekol'nikov, B.S. Semyonov, E'.I. Veremej [On the technological conditions of veterinary services for dairy complexes] Mezhdunarodny j vestnik veterinarii. - SPb [nternational Journal of Veterinary Medicine. - SPb], 4, 8.

36. Timofeev S.V. (2007). Obshhaya khirurgiya zhivotny`kh: uchebnik dlya vuzov/ S.V. Timofeev, Yu.I. Filippov, S.Yu. Konczevaya, S.V. Pozyabin, P.A. Soldatov, S.M. Paninskij, D.A. Dervishov, N.P. Ly`senko, V.A. Ermolaev, M.Sh. Shakurov, V.A. Chervanyov, L.D. Troyanovskaya, A.A. Stekol'nikov, B.S. Semyonov. [General Animal Surgery: University Textbook ] M.: OOO «Zoomedlid» [M .: LLC "Zoomedlid"], 670.

37. Semyonov B.S. (2013). Khirurgicheskie bolezni konechnostej u molochny kh korov / B.S. Semyonov, V.N. Videnin, N.V. Pilaeva, G.Yu. Savina [ Surgical limb diseases in dairy cows] Voprosy` normativno-pravovogo regulirovaniya v veterinarii [ Regulatory issues in veterinary medicine], 3, $107-109$.

38. Shnyakin, A.V. (2012). Gnojno-nekroticheskie zabolevaniya pal'czev u krupnogo rogatogo skota v zone Yuzhnogo Urala / A.V. Shnyakin, T.N. Shnyakina, N.P. Shherbakov [ Purulent necrotic finger diseases in cattle in the zone of the South Urals] Vestnik Altajskogo gosudarstvennogo agrarnogo universiteta [ Bulletin of Altai State Agrarian University], 10 (96), 108-110.

39. Yakob, V.K. (2013). Bolezni kopy`tecz u korov v razny'kh stranakh mira / V.K. Yakob, V.A. Ermolaev [Diseases of the hooves of cows in different countries of the world] Materialy` Mezhdunarodnoj nauchno-prakticheskoj konferenczii «Agrarnaya nauka i obrazovanie na sovremennom e tape razvitiya: opy`t, problemy` i puti ikh resheniya». - Ul'yanovsk: GSKhA im. P.A. Stoly pina [ Materials of the International scientific-practical conference "Agricultural science and education at the present stage of development: experience, problems and solutions". - Ulyanovsk: State Agricultural Academy named after P.A. Stolypin], 2, 220-226.

A. Stotskiy, PhD snudent, Sumy National Agrarian University, (Sumy, Ukraine)

O. Stotskiy, associate professor, Sumy National Agrarian University, (Sumy, Ukraine)

Distribution and structure of diseases in cows in the holdings of the republic of Kazakhstan and Georgia

It was found that among the surveyed cows that were being kept in an open free-stall system, the number of detected diseased animals at the Martcopy - Baga dairy farm (Georgia) exceeded that of the farming Tabys (Kazakhstan). The cows that were in the territory of Georgia diseases of the distal extremity (pododermatitis, phlegmon) were detected in more than a quarter of the animals and exceeded the indicator in the farming of the Republic of Kazakhstan.

Endometritis were diagnosed more frequent in Tabis farm, almost 25\%, while on the Martcope - Baga dairy farm, their percentage was by $11,25 \%$ lower.

Tabis.

Mastitis are registered in both farms almost in equal percentages of animals, with larger numbers, by 0,28\%, in the farming

When analyzing the productivity per cow, we found that the cows of the farming of the Republic of Kazakhstan had yield of milk on a level 7,5 thousand, while the dairy farm of Georgia had about 8 thousand liters. It should be noted that in the farms were open free-stall system, about 40 to 50 animals in one holding pen round the year. In the external examination of heifers, we found about $40 \%$ of animals in the Martcopy-Baga dairy farm that had distal extremity disease (purulent pododermatitis, coronary band, interdigital claw and digital cushion phlegmons,) while heifers with similar diseases in farming Tabis were less by 2,09 times. One of the main causes of diseases of the distal extremity in the cattle at the Martcope - Baga dairy farm is the untimely orthopedic cleansing of the hooves, which also contributed to their deformation and change motor supply of limbs in animals. In these farms, the number of kept animals varied significantly.

Thus, in the Martcope - Baga dairy farm were 96 heifers less than in the farming Tabis and the structure of the detected diseases also had some difference. Deformations of hooves were reported by $11,33 \%$ more often in the Martcope - Baga dairy farm than in the farming Tabis which was one of the reasons for the inflammatory process of the finger area.

The largest percentage among the deformities of the hooves in the surveyed farms were acute-angled hooves, which were recorded in almost 10,0\% of cows in the farm of Georgia and exceeded the indicator by 1,67 times in the farm of the Republic of Kazakhstan. A fairly large percentage of hooves deformities in animals in the surveyed farms accounted for acute and crooked hooves, ranging from 5-9 percent. It should be noted that these deformations were more widespread in the Martcope - Baga dairy farm.

Analyzing the data on other deformations, statistic of diseases had higher rates in the farm of Georgia. Thus, the percentage of obtuse hooves in the Martcopy - Baga dairy farm exceeded the similar in the farming Tabis by 1,65\%, flat by 3,04\% and almost at the same level in the distribution of the percentage of complete.

Key words: orthopedicpathology, endometritis, mastitis.

Дата надходження до редакції: 15.02.2019 p. 